\title{
A História de Alda : ensino, classe, raça e gênero
}

Marília Pinto de Carvalho

Universidade de São Paulo

\section{Resumo}

Este artigo analisa a trajetória de vida e a prática pedagógica de uma professora das séries iniciais de uma escola pública da cidade de São Paulo, tendo como referência o conceito de cuidado infantil. Tomado como expressão das formas que histórica e culturalmente assume a relação adulto / criança, o cuidado infantil pode ser definido, hoje, neste nível de ensino, como uma atuação do professor ou professora sobre aspectos extracognitivos do desenvolvimento de seus alunos, o que exige uma postura de envolvimento afetivo e compromisso com as crianças. Por meio de um estudo de caso de enfoque etnográfico, discute-se a presença do cuidado nos ideais e práticas pedagógicas de Alda, uma professora que não realizava plenamente essas prescrições. Trata-se, nesse sentido, de uma aproximação que permite revelar os limites de abordagens essencialistas, em que estão relacionados, linearmente, a feminilidade e aqueles ideais de professora. De um lado, acentua-se, aqui, o sentido plural das diversas formas de feminilidade, suas articulações com relações de classe e raça; e, de outro lado, indica-se que as prescrições de cuidado fazem parte de uma cultura escolar, produzida e reproduzida na própria instituição, mais do que em formas específicas de socialização feminina. A história de Alda indica a necessidade de discutir o racismo no interior das escolas, a começar do próprio corpo docente. E mostra que, se estamos convencidos da relevância das práticas de cuidado para o ensino, é preciso trazê-las, criticamente, ao primeiro plano nas discussões pedagógicas, para que adquiram legitimidade como parte de uma prática profissional.

\section{Palavras-chave}

Correspondência para:

Ensino Fundamental - Trabalho Docente - Relações de Faculdade de Educação Gênero - Etnia. 


\section{Alda's Story : teaching, class, race and gender}

Marília Pinto de Carvalho

Universidade de São Paulo

Correspondence:

Universidade de São Paulo

Faculdade de Educação

Av. da Universidade, 308 -

sala 210

05508-900

Cid. Universitária - SP

email: mariliac@usp.br

\section{Abstract}

This paper analyses the history of life and the pedagogical practice of a first grade teacher of a public school in São Paulo City having the concept of childcare as a reference. The concept of childcare is taken as an expression of the forms the relationship adult/child takes historically and culturally. As such it can be defined, at that level of teaching, as an intervention of the teacher on extra-cognitive aspects of the development of his/her pupils, an attitude that requires emotional involvement and commitment to the children. Based on an ethnographic study the presence of the care in the ideals and pedagogical practices of Alda - a teacher that did not fully comply with those guidelines - is discussed. It is in that sense an approximation that reveals the limits of essentialist approaches that establish a linear relation between "femininity" and the ideal of a teacher. On one hand, the plurality of meanings of femininity, and their articulation with class and race relations, is stressed. On the other hand, it is suggested that the guidelines related to care are part of a school culture produced and reproduced within the institution itself, rather than in specific forms of feminine socialization. Alda's story shows the need to discuss racism inside schools starting with the teachers themselves. It also shows that, if there is a certainty that practices of care are relevant to teaching, it is necessary to bring them to the center of the pedagogical debate so that they gain legitimacy as a professional practice.

\section{Key words}

Basic Education - Teaching Work - Gender Relations Ethnicity. 
Neste artigo, analiso a trajetória de vida e a prática pedagógica de uma professora das séries iniciais' de uma escola pública da cidade de São Paulo. Trata-se de um excerto de minha tese de doutoramento (Carvalho, 1998), um estudo que, tendo como referência de análise as relações sociais de gênero, propôs-se a interpretar o trabalho docente no ensino primário, a partir do conceito de cuidado infantil. Este conceito foi tomado como expressão das formas que, histórica e culturalmente, assume a relação adulto / criança (neste caso específico, no interior das escolas primárias). 0 cuidado infantil, uma relação que incorpora tanto as assimetrias e hierarquias de gênero quanto as de idade, pode ser definido, hoje, neste nível de ensino, como uma atuação do professor ou professora sobre os aspectos extracognitivos do desenvolvimento de seus alunos: aspectos físicos, emocionais, morais etc., o que exige dele ou dela uma postura de envolvimento afetivo e compromisso com as crianças. Por intermédio de um estudo de caso de enfoque etnográfico, que envolveu a realização de entrevistas e observações, inclusive em sala de aula, com quatro professoras e um professor, a pesquisa concluiu que há presença marcante do cuidado nos ideais e práticas pedagógicas dos sujeitos. ${ }^{2}$ E discutiu as relações historicamente construidas entre as prescrições de boa maternidade e os ideais de professora primária, apontando a existência de uma matriz comum a esses dois modelos, ambos referidos a uma idéia de infância prolongada e afastada do trabalho e também a um ideal de maternidade to$t a l,{ }^{3}$ em que uma mulher adulta deve se responsabilizar integralmente pelos diferentes aspectos do desenvolvimento infantil.

Aqui, apresento especificamente a história de Alda, ${ }^{4}$ uma professora que não realizava plenamente essas prescrições de boa professora primária, isto é, não correspondia ao modelo ideal de professora dedicada, envolvida emocionalmente com seus alunos e responsável por aspectos de seu desenvolvimento para além do aprendizado intelectual. Trata-se, nesse sentido, de uma aproximação à discussão do cuidado no espaço escolar pela negativa ou pelo avesso, que permite revelar os limites de abordagens essencialistas em que estão relacionados, linearmente, a feminilidade e esses ideais de professora. De um lado, acentua-se, aqui, o sentido plural das diversas formas de feminilidade, suas articulações com relações de classe e raça; e, de outro lado, indica-se que as prescrições de boa professora fazem parte de uma cultura escolar, produzida e reproduzida na própria instituição, mais do que em formas específicas de socialização feminina.

\section{A professora}

Em 1996, com 45 anos de idade e 16 de experiência no ensino, Alda era a única professora negra ${ }^{5}$ da escola pesquisada. Era, também, a única de origem nordestina - nascera em Recife - e a única mãe solteira, com um filho de sete anos. Entre os demais professores e professoras daquela escola, apresentava uma qualidade de vida sensivelmente inferior, sendo a responsável exclusiva pelo sustento próprio e do filho, e ocupando-se, à tarde, com serviços de costura, para complementar o orçamento.

1. Para simplificar a longa nomenclatura "quatro primeiras séries do ensino fundamental" e dar destaque à especificidade dessas séries ante as demais, utilizo seu nome historicamente consagrado "ensino primário", e, para seus docentes, o correspondente "professora primária".

2. Foram realizadas ao todo 95 horas de observação, entre março de 1996 e março de 1998, e três entrevistas com cada professor/a (maio, junho de 1996; outubro, novembro de 1997; e março de 1998).

3. A expressão "maternidade total" tem sido utilizada para descrever as prescrições de maternidade predominantes no Ocidente nas últimas décadas e que responsabilizam as mães por todas as facetas do desenvolvimento de seus filhos, especialmente as psicológicas, exigindo delas uma presença constante e prolongada em meio às crianças (David, 1993; Haddad, 1987; Lightfoot, 1977; Manicom, 1984, Novelino, 1989).

4. Todos os nomes de pessoas e instituições são fictícios.

5. Refiro-me à cor da pele e a outros traços fenotípicos, a partir de minha própria opinião (hetero-atribuição). Por tomar como referência esses dados fenotípicos, falo em raça e não em etnia. 
Esse conjunto de condições colocava Alda numa situação de isolamento dentro do grupo, embora poucas pessoas admitissem qualquer preconceito contra ela. A própria Alda comentava um distanciamento social, mas não falava abertamente sobre a cor de sua pele, e não punha o racismo como central em suas dificuldades de relacionamento com o grupo de professores e professoras:

Eu sinto uma relação péssima. [...] E eu estou achando um ambiente assim muito... burguês. Uma burguesia em termos financeiros, uma burguesia em termos de conhecimento. [...] Elas estão num pedestal lá na altura.

Durante todo o período da pesquisa, seja em entrevistas formais, seja em conversas informais, eu mesma não consegui mencionar diretamente com Alda a questão racial, embora falássemos diversas vezes em discriminação e preconceito em geral. Entre todas as pessoas da escola, algumas explicitamente preocupadas com o isolamento em que Alda se encontrava, apenas a então diretora, Sônia, falou-me em racismo: "Alda é uma pessoa complicada, problemática, está se isolando, se afastando do grupo. Por mais que a gente não queira, a questão da cor da pele... [gesto de passar a mão no próprio braço]". Alda citou uma única vez a questão racial, durante a primeira entrevista, assim mesmo para negar qualquer discriminação nesse aspecto, quando pedi que explicasse melhor sua experiência como professora numa cidade do interior de São Paulo, onde disse que as pessoas eram muito preconceituosas:

Quanto à raça eu não... não percebi, não deu prá eu perceber, mas quanto a esse preconceito de casamento, comportamento religioso. Preconceito de... [...] as moças eram muito ligadas à virgindade, entende?

Dentro do grupo de professores e professoras, a questão de ser mãe solteira parecia me- nos problemática. 0 fato era de conhecimento de todos, já que o filho de Alda estudava na própria escola pesquisada, mas, em geral, falava-se apenas sobre um contexto mais abrangente de dificuldades: "Eu sei que ela tem uma vida muito sofrida" (Profa. Maria Rosa).

Diversos autores têm chamado a atenção para o silêncio sobre a questão racial no Brasil, freqüentemente reduzida, tanto no senso comum, quanto nas Ciências Sociais, a mera conseqüência da situação sócio-econômica, como se a diferença racial não tivesse efeitos específicos sobre o acesso aos bens materiais e simbólicos (Rosemberg, 1998; Silva e Hasenbalg, 1992). Particularmente, no caso de professoras negras, estudo de Nilma Lino Gomes (1994) com um grupo de professoras mineiras destaca a dificuldade das próprias protagonistas em afirmar-se do ponto de vista racial e em reconhecer a discriminação, apontando que a força do silêncio e da negação é equivalente à dor que enfrentar a questão significaria. Assim, parte de suas entrevistadas, tal como Alda, descreviam a si próprias como "morenas" ou outras nuances do tipo, tendiam a só perceber como negras outras pessoas, e a silenciar, seja sobre sua própria cor, seja sobre situações que percebiam como discriminatórias.

A origem pobre e pernambucana de Alda, que veio de Recife em 1977, evidenciava-se, principalmente, em sua fala. Embora ela não tivesse um sotaque regional carregado, dificilmente concordava adjetivos, artigos e substantivos quanto ao plural e singular. Além disso, essa era uma herança que Alda valorizava, mencionava e utilizava como referência, seja para compreender os alunos, seja para situar sua própria trajetória: "Só quando vim para São Paulo é que vi pobreza, sujeira e falta de educação andarem juntas. Eu nunca fui rica e não sou sem educação".

Na época da pesquisa, o Nordeste permanecia como um horizonte para Alda, que 
comentou uma viagem nas férias de julho de 1996 para Natal e Recife e planejava voltar para alguma cidadezinha pequena da região, onde pudesse trabalhar com alfabetização, "levar uma coisinha a mais para o Nordeste. Não que aqui não haja pobreza, mas lá... vou ajudar mais, contribuir". Essa menção ao sonho de voltar para o Nordeste foi o único momento em que a observei falando com idealismo de seu trabalho, associando-o a uma possibilidade de ajudar os outros ou melhorar o mundo.

Por outro lado, a herança nordestina também era fonte de problemas naquilo que Alda parecia mais valorizar em si mesma: sua formação escolar.

\section{É muito complicado aqui uma discriminação. A} criança chega aqui mal alfabetizada: se ela veio da Bahia, isso é motivo, porque ela veio da Bahia. Se ela veio de Pernambuco, isso é motivo, porque veio de Pernambuco, do Nordeste. Só que quando a criança sai mal alfabetizada daqui, é o motivo de quem? Porque São Paulo é colocado como o berço do saber, onde tudo é perfeito.

\section{Como mostrou Antônio Flávio Pierucci} (1987), em estudo sobre a Nova Direita em São Paulo, atitudes e sentimentos discriminatórios contra os imigrantes pobres do Nordeste do país fazem parte da mentalidade de grupos significativos dentro dos setores médios paulistanos, que relacionam a presença desses imigrantes com o aumento da criminalidade, da insegurança, do desemprego e da vadiagem, e com o desgaste e superlotação dos serviços públicos e do próprio espaço urbano.

Falando sobre a discriminação contra os alunos, Alda certamente falava do que ela própria enfrentara: tendo se formado no curso de Magistério em Olinda, ficou três anos em São Paulo trabalhando como balconista e atendente de enfermagem, porque acreditava não estar capacitada para lecionar neste estado e haviam lhe informado que seu diploma não teria validade.
Vencida a barreira inicial, trabalhou como professora eventual (substituta). Depois, conseguiu sua própria classe, prestou concurso e efetivou-se em 1986. Mudou bastante de escola desde então, tendo ficado pouco tempo em cada uma. Em 1987, concluiu curso superior de Pedagogia numa faculdade particular da Capital e mostrava grande orgulho pelos cursos de aperfeiçoamento que vinha fazendo desde então, mencionando-os diversas vezes em conversas e durante as entrevistas.

0 saber escolar, a formação acadêmica eram valores importantes para Alda, símbolos de diferenciação e status social, como se pode depreender da maneira como respondeu a minha pergunta sobre a profissão de seu pai, acrescentando a informação sobre seu grau de escolaridade: "0 meu pai, ele era operário. Uma pessoa analfabeta, não sabia ler". Comparando seus primos e primas com seus sete irmãos e irmãs, ela disse que sua própria família "é a mais selecionada", ressaltando que, apesar de um irmão que "não conseguiu ser alfabetizado", todos os demais tinham, pelo menos, o ensino médio completo e um deles, o mais novo, que era policial, estava "cursando Direito no Mackenzie".

Gomes, no estudo mencionado, situa a importância da educação formal e da carreira de magistério, ao lado de outras carreiras no serviço público, no projeto de ascensão social da população negra, como parece ter sido o caso da família de Alda. ${ }^{6}$

A constante solidão e insegurança da professora pareciam ser indicadores do quanto ela se sentia fora do lugar, num espaço

6. Essa estratégia de ascensão social por meio da educação formal parece, além disso, bastante realista. Estatísticas indicam que as mulheres não brancas com escolaridade de $3^{\circ}$ grau conseguem níveis de rendimento uma vez e meia maiores do que aquelas com $1^{\circ} \mathrm{grau}$ incompleto. Embora em cada um dos níveis de escolaridade seus rendimentos mantenham-se abaixo tanto das mulheres brancas quanto dos homens de todas as raças, é o grupo das mulheres não brancas que obtém um maior diferencial a partir da variável grau de escolaridade (Lavinas et alli, 1998). 
social pelo qual havia lutado muito, mas onde era considerada inadequada, exceção, um espaço que não era seu destino natural, especialmente por se tratar de uma escola localizada em bairro de camadas médias abastadas, bem considerada ante a Delegacia de Ensino e a comunidade, procurada por professoras em fim de carreira, que residiam nas proximidades. Diferentemente delas, todas originárias de famílias dos setores médios paulistas e, quando casadas, com maridos que exerciam funções qualificadas de gerência ou supervisão, Alda morava num pequeno apartamento alugado no centro da cidade, provinha de uma família proletária e tivera uma infância difícil, com o pai aposentado muito cedo por acidente de trabalho e a necessidade de ajudar a mãe no serviço doméstico desde os sete anos de idade.

É interessante pensar na alternativa encontrada por Alda para complementar seu salário - o trabalho de costureira -, especialmente se confrontada a sua situação com a de outra professora da mesma escola, que complementava o salário dando aulas particulares de matemática. Não possuindo curso superior, aquela outra colega alegava utilizar, nessas aulas, apenas o que aprendera durante sua escolarização básica, enquanto Alda, que possuía diploma de Pedagogia, lançava mão de um aprendizado informal ligado a sua socialização feminina e que originava uma ocupação desprestigiada socialmente. A qualidade da educação escolar básica, aqui, era um fator importante, que ampliava a diferença de status social entre as duas professoras, ao lado de outros elementos como a renda familiar, a raça e a origem geográfica.

Enquanto a outra professora relatava a gratificante experiência escolar que tivera desde os primeiros anos, numa escola bem estruturada, inovadora e sólida do ponto de vista pedagógico, Alda parecia estar falando de outro mundo:

Minha mãe pagava pessoas sem o menor preparo. A primeira professora que eu tive, era assim na casa dela mesmo, minha lembrança é dela fazendo o mingau do filho dela no fogão e eu na mesa, que era bem perto, tentando fazer o alfabeto. [...] Não me lembro do nome dela. Eu ali fazendo o alfabeto, tinha que ser com a letra bem bonita. Mas não consegui me alfabetizar.

A segunda tentativa foi numa classe que funcionava numa igreja. Alda também não se lembrava do nome da professora, apenas do medo que sentia ante suas ameaças de trancar as crianças num quarto escuro. Mais uma vez, não aprendeu a ler e escrever.

Então fui para uma escola de verdade. Era longe, tinha que atravessar a principal avenida, que ligava o bairro ao centro, andar muito. [...] 0 nome da professora era Alda. Veja só, Alda também. Isso me marcou muito. Quando eu aprendi a ler, ela me deu um broche, foi na volta das férias.

Sem uma experiência escolar sólida em que se apoiar, Alda enfatizava, pelo menos num primeiro nível de seu discurso, a necessidade de atualização constante para um bom desempenho em sua profissão: "Olha, a minha maior preocupação, a minha aflição é que eu gostaria de estar sempre nessa roda viva de conhecimentos". Apenas numa situação ela falou em dar "carinho e atenção" em substituição a um trabalho propriamente pedagógico: no início de sua carreira, quando tinha uma classe de crianças com muitas dificuldades de alfabetização, diante da qual ela se sentia despreparada. Mesmo assim, enquanto "dava assistência" e percebia que as crianças gostavam dela, Alda inscreveu-se num curso da APAE (Associação de Pais e Amigos de Excepcionais) para professores de classes especiais: "Um curso caríssimo, que eu paguei [...] porque eu estava pensando naquelas crianças, que eu tinha que ter outras formas, eu tinha que estar preparada melhor". 
Nesse caso, a necessidade do curso e da capacitação técnica nasceu da preocupação com as crianças, do compromisso que, num primeiro momento, expressara-se apenas em atenção e carinho. A noção de responsabilidade, de precisar preparar-se para dar conta do trabalho pedagógico era muito presente nas falas de Alda. Mas lamentava:

Eu não tenho condições de sair uma noite até a USP ou a PUC ou seja lá onde for, para fazer um curso, porque eu tenho que ficar em casa fazendo uma barra de calça para alguém me pagar $R \$$ $5,00, \mathrm{R} \$ 3,00$.

No conjunto das entrevistas e de nossas conversas, chama a atenção o fato de Alda mencionar, com certa freqüência, suas falhas, mas não falar sobre soluções que tenha adotado, experiências bem sucedidas, seu método de ensino, que ela classificava apenas como "moderno", em oposição a outros/as professores/as que acusava de "tradicionais". Essa ênfase nos erros provavelmente decorria da situação de marginalização que Alda vivia na escola (e na vida), gerando uma insegurança certamente ampliada pela situação de entrevista; e, ao mesmo tempo, parecia relacionar-se a fragilidades reais de formação.

Alda enfatizava como qualidades importantes de uma boa professora o compromisso com as crianças e a capacidade de perceber cada nova situação e adaptar-se, colocando o aprendizado da profissão na prática como fundamental, como fazem freqüentemente as professoras (Ludke, 1996; Tardif et allii, 1991).

Eu acho que é difícil chegar para a professora e dizer como ela pode trabalhar. [...] Ela vai sentir o impacto. Quando ela chegar na sala de aula propriamente dita, que ela é responsável por aquelas crianças, ela vai sentir o impacto.

Também insistia na necessidade da humildade de querer aprender, perguntar, observar o trabalho das colegas e na capacidade de criar a partir das sugestões e experiências transmitidas. Ela mesma, entretanto, não tinha encontrado muitas pessoas com quem aprender, com quem pudesse contar:

Eu fui aprendendo ali junto com a criança, verificando, observando, pegando livro. Eu ia atrás de tudo que pudesse me ajudar, porque poucas pessoas estavam à disposição para me ajudar. Mas foi mesmo me atropelando na vida que eu fui aprendendo.

Assim, quando se tratava de discutir concretamente os conhecimentos aplicados em sala de aula, nenhum curso, com exceção daquele da APAE, foi mencionado por Alda, nem mesmo os cursos de Magistério ou de Pedagogia. Quanto às leituras, ela falou genericamente de livros didáticos, jornais e revistas, dos quais "tirava muitas coisas importantes para alfabetização”.

\section{Alda na sala de aula}

A mais forte impressão que tive das aulas de Alda era de uma certa confusão, dispersão e improviso. As ordens que ela emitia eram contraditórias, pouco claras, diversas vezes ela se arrependia, voltava atrás e mudava o pedido. Freqüentemente, Alda consultava cadernos de alunos para saber o conteúdo de exercícios que passara, às vezes, há poucos minutos; noutros momentos, alunos e alunas vinham perguntar a mim ou questionavam-se entre si o que era para fazer, pois não tinham compreendido a tarefa. 0 próprio clima na sala de aula era disperso, com poucos minutos de concentração e silêncio. Alda quase sempre estava ocupada em mais de uma atividade simultaneamente: corrigia cadernos de Português, enquanto os alunos faziam o exercício de Matemática; preparava a aula do dia seguinte, enquanto eles resolviam questões na lousa; preenchia fichas, enquanto as crianças desenhavam etc. 
Mais do que a dispersão do trabalho docente descrita por Philipe Perrenoud (1993) uma dispersão em parte inevitável, em parte resultante do acúmulo de projetos e propostas inovadoras de trabalho -, Alda aparentava falta de tempo, pressa e improviso. Ela não podia permanecer nem um instante a mais na classe ou na escola e nenhuma tarefa podia ser levada para casa, onde tomavam todo seu tempo as atividades domésticas, a atenção ao filho e o trabalho de costura. Assim, estava sempre dividida. Sem uma preparação prévia e sem uma base sólida em que se apoiar, mesmo suas tentativas de criar situações interessantes e inovadoras para a aprendizagem quase sempre resultavam confusas e pouco produtivas.

A precariedade da formação intelectual de Alda evidenciava-se a cada momento, na sala de aula, dificultando ainda mais sua situação. Ela tinha muitos problemas com os plurais, mesmo na língua escrita: certa vez, por exemplo, anotou na lousa um exercício em que se lia "Pesquisar e escrever no caderno: 2 palavras oxítona, 2 palavras paroxítona, 2 palavras proparoxitona". Em outros momentos, teve dúvidas sobre a grafia da palavra dezesseis, falou em "menas gordura" ou escreveu questões como: "Onde você acha que passa a história?". Alda, certamente, tinha consciência dessa precariedade de formação, o que se evidenciava em sua ênfase para comigo quanto aos cursos de atualização e reciclagem que havia feito e em sua insegurança, sem dúvida ampliada por minha presença em sala de aula. 0 senso agudo de responsabilidade que essa professora demonstrava, diante da consciência de suas próprias limitações, eram seguramente fonte de sofrimento e mesmo vergonha.

Quando lhe perguntei como se sentira durante as observações em classe, ela foi franca: "É, não deixa de incomodar, sim... eu me senti assim nua”. A referência à nudez me pareceu particularmente tocante, pois estava no corpo, na cor da pele, uma das principais fontes de discriminação contra Alda e que repunha, perma- nentemente, sua situação de subalternidade também diante de mim, pesquisadora branca.

Descontada a interferência provocada por minha presença, contudo, parece que ainda restava uma boa dose de insegurança, ansiedade e improviso, como indicaram as opiniões dos alunos de que as aulas não eram diferentes quando eu assistia a elas ou não. A sensação de incerteza e variabilidade das regras levava as crianças a uma constante agitação e produzia uma sensação na classe de que ninguém, nem mesmo a professora, sabia muito bem aonde iriam chegar. Às vezes, era permitido falar; noutras, não; às vezes, podia-se ir ao banheiro, sem sequer perguntar à professora; noutras, o pedido era negado. Alda deixava os alunos quase sempre sem nenhum limite e só intervinha quando a situação - uma briga, gritos - já estava completamente fora de controle.

Assim, Alda não parecia ter incorporado, em sua prática, o modelo de professora primária fundamentado nas prescrições de cuidado e na maternidade total. Em novembro de 1996, lecionando para uma única classe desde agosto ${ }^{7}$, ela não sabia ainda os nomes de todos os seus 27 alunos. Suas interações com eles eram quase sempre ríspidas, nervosas e apressadas, apesar de um certo esforço em não discriminar crianças que não dominavam conteúdos, explicar mais de uma vez e não deixar questões sem respostas. Talvez se pudesse aplicar à sua relação com os alunos o que ela me disse sobre sua relação com o filho: "Estou muito cansada, estressada, é tudo muito repetido, em casa, na escola. Estou que não agüento mais. Fico sem nenhuma tolerância, sem paciência”.

Alda parecia não contar com uma disponibilidade emocional que lhe permitisse um

7. Durante o primeiro semestre de 1996, as três professoras de terceira série da escola pesquisada haviam dividido entre si as disciplinas, cabendo a Alda lecionar Estudos Sociais e Educação Física para as três turmas. Porém, em agosto, avaliando que a experiência não tivera bons resultados, voltaram a ter uma professora polivalente por classe. 
maior envolvimento com seus alunos, pois é, antes de mais nada, sobre si mesma que ela responde, ao falar sobre como seria um professor ideal:

Um professor ideal... é... seria uma coisa muito boa, não é? Acho que ela precisaria estar totalmente desprovida de outras coisas, até da própria vida dela, pessoal. Para poder se dedicar totalmente a sua profissão, em termos mais amplos, tanto na parte que ela tenha um bom conhecimento pedagógico, como ela também tenha um bom conhecimento na parte psicológica (ênfase minha).

Em primeiro lugar, gostaria de destacar, nesta fala, a passagem do masculino, gênero no qual foi feita a pergunta ("Como você caracterizaria um professor ideal?”), para o feminino, quando Alda começou a falar da pessoa que estava imaginando, indicando que provavelmente fazia parte desse ideal ser uma mulher. Em relação ao homem professor, Alda raciocinava a partir de sua experiência com seu pai, deduzindo a postura do professor a partir do pai tradicional:

A gente já vê o homem mais radical, mais aluno para lá e eu para cá. Um pai em casa - eu não sei, porque eu não criei o meu filho com pai -, mas, em casa, eu, minha mãe e meu pai, o meu pai era um pouco mais fora da situação. [...] Como professor, eu não sei que relação de mais íntimo ele passa para seus alunos, assim, mais perto.

Parece que o principal problema que Alda localizava no professor de sexo masculino seria a dificuldade em cuidar dentro das prescrições predominantes, ter uma relação mais afetuosa com as crianças, pois o modelo de pai que conheceu na infância, assim como sua criação em geral, correspondia a outro modelo de cuidado:

0 meu pai é um homem assim muito exigente. [...] Era assim ... tratava a gente com agressão, com agressão. Não havia conversa, não havia papo, não havia diálogo. Era surra mesmo, era surra pesada mesmo, assim na maior agressividade. Não havia uma conversa.

Em segundo lugar, ainda quanto à fala de Alda sobre "a professora ideal”, é importante destacar o padrão ante o qual ela avaliava sua própria prática docente: uma professora absolutamente dedicada, cujo envolvimento com a profissão não estivesse limitado sequer por sua vida pessoal. Embora tenha pontos em comum com o ideal de maternidade total, pela dedicação e entrega que exigiria, Alda refere-se, de forma ambígua, a um envolvimento com "a profissão": trata-se apenas de ter disponibilidade para estudar, fazer cursos e obter os saberes que o trabalho docente exigiria ou de um envolvimento pessoal com os alunos, um vínculo emocional?

Na prática de sua relação com as crianças, Alda parecia manter-se distante emocionalmente das crianças. Nunca a vi abraçada com qualquer deles, os beijos, ao final das aulas, eram raros e envergonhados, pelo menos diante de mim; as lembranças e casos relatados pela professora nunca se referiam a um aluno em particular, não mencionavam vínculos, saudade, carinho partilhado ou mesmo conflitos específicos; e, ainda, as interações em sala de aula eram quase sempre dirigidas à classe como um todo ou a grupos dentro dela, mesmo quando eram reprimendas.

Quanto às crianças, tanto seus atuais quanto ex-alunos diziam gostar de Alda. Mas a característica que pareciam mais apreciar nela, em comparação a outras professoras, era ser pouco exigente e não cobrar seu empenho: "Ela é boazinha. A professora do ano passado era muito exigente, muito brava" (aluna da 3a série, 1996); "Ela explica mais de uma vez, se a gente não entende. E se a gente não fizer às vezes ela não liga" (aluno da $3^{\text {a }}$ série, 1997). 
Alda mostrava ter preocupação com a vida de seus alunos fora da escola, mas tendia a culpar as famílias e, especialmente, as mães por desleixo, pouco caso ou desatenção, seja por permitir que um aluno com grande problema visual fosse à escola sem os óculos, seja por não tratar adequadamente de ferimentos, seja por não colaborar nas tarefas escolares, reproduzindo estereótipos bastante divulgados em nossas escolas públicas sobre mães que vêem a escola apenas como "depósitos de crianças". Ela percebia certas dificuldades ou situações que considerava preocupantes - como um aluno com problemas dentários, um menino que só gostava de brincar com meninas ou crianças que eram ridicularizadas pelos colegas -, mas agia ante elas somente o mínimo indispensável e já esperado, como mandar um bilhete para a mãe ou dar um conselho ao aluno.

Em duas ocasiões, durante as observações, Alda manifestou preocupação com aspectos de saúde e higiene das crianças como grupo: numa aula sobre verminose, em que acrescentou ao texto extraído de um livro didático conselhos práticos, como "não comer um lanche que caiu no chão"; e, numa ocasião, na saída do recreio, em que criticou os meninos suados pelo mau cheiro, numa abordagem que me pareceu, porém, humilhante.

Perguntada sobre as tarefas que caberiam ou não ao professor, Alda enfatizou a sobrecarga a partir de exigências dos órgãos oficiais, como o controle das cadernetas de vacinação das crianças; ${ }^{8}$ e a existência de uma confusão por parte das famílias quanto ao papel da escola e das professoras. E excluiu de sua alçada a aquisição de limites e boas maneiras, os problemas de saúde, a solução de dificuldades materiais e, especialmente, os problemas emocionais:

Olha, eu coloco essa assistência emocional, essa parte emocional fica meio difícil para mim lidar com isso. Então, eu já peço apoio para um profissional da área. [...] Tem uma criança agora que tem um problema emocional em casa, a mãe já sabe disso, ele trazendo [esses problemas] para a escola... E estava me deixando em desespero, porque qualquer coisa que eu cobrasse dele, ele caía em prantos, chorando.

Outro professor da mesma escola, um dos raros homens lecionando nas séries iniciais, falou-me abertamente sobre seus sentimentos ambíguos em relação às crianças, o fato de não ter apego à docência e pensar em deixar a profissão. Diferentemente, Alda parecia sentir-se mais atada a um script prévio, o script feminino da dedicação às crianças, e em nenhum momento mencionou para mim a vontade de se afastar do magistério. Levando em consideração as prescrições quanto à boa professora e sua imbricação com os ideais de feminilidade, parece mesmo mais difícil para uma mulher do que para um homem admitir raiva, falta de paciência com crianças, desinteresse pelo magistério, uma vez que isso poderia colocar em questão não apenas sua identidade profissional, mas sua própria feminilidade. 0 que possivelmente era ainda mais agudo no caso de Alda, em que as demais condições, além do sexo, estavam em desacordo com a imagem ideal de professora primária, por ser negra, mãe solteira e lutar com dificuldades econômicas. Além disso, há que se considerar a falta de outras opções profissionais no horizonte da professora, que, contando com todas as restrições do mercado de trabalho ligadas ao fato de ser mulher e negra, precisava do emprego para manter-se, não tinha perspectivas de ascensão na carreira e não podia contar com apoio familiar ou de relacionamentos sociais na busca de alternativas.

\section{Alda e as prescrições de cuidado}

Ao falar de seu trabalho na escola, Alda não deixava de mencionar as crianças: suas

8. Em 1996, durante um surto de sarampo, os professores foram encarregados de controlar a vacinação de seus alunos. 
condições de vida, as diferenças entre cada escola onde trabalhou - favela, loteamento da periferia, cidade do interior, escola em bairro central. Com relação aos alunos da escola pesquisada, foi a professora que mostrou a percepção mais acurada das diferenças sociais entre eles, mencionando como relevante o número de crianças oriundas de camadas médias, que seriam cerca de um terço: "gente que põe o filho na escola pública prá guardar dinheiro prá passear, sair, porque pagar escola particular tá fogo".

Essa percepção, diferente da predominante na escola e mais de acordo com os dados estatísticos, parece estar articulada à ausência de uma postura moralista e filantrópica de Alda ante seus alunos. Dispondo de uma posição social próxima à das crianças mais pobres dentro do grupo atendido pela escola, Alda não percebia seu trabalho como missão ou humanitarismo e não justificava sua permanência no magistério por um compromisso desse tipo, como tendiam a fazer suas colegas (Carvalho, 1998). Isso a deixava em melhores condições de apreender a diversidade social existente entre seus alunos, parte deles dispondo de uma qualidade de vida superior à da professora.

Todavia, Alda não mencionou qualquer caso de aluno em particular, nenhum sentimento marcante de afeto ou rejeição por essa ou aquela criança. Essa postura também a diferenciava das demais professoras entrevistadas, que tendiam, pelo contrário, a remeter a conversa, constantemente, para casos individuais, citando nomes, casos e histórias que haviam vivenciado com alunos, para responder a minhas questões.

Em mais de uma ocasião, Alda deixou claro que, para ela, o magistério era um trabaIho como outro qualquer, do qual ela gostava, mas sem nenhum apelo a falas sobre vocação, destino ou amor pelas crianças. "É o meu salário, é o meu emprego, eu agradeço a Deus por ele... é meu." 0 curso de Magistério foi feito por acaso, a escola disponível próxima à sua casa era uma Escola Normal. 0 emprego como pro- fessora surgiu como uma oportunidade de sobrevivência na cidade grande, numa época em que "o salário não era tão baixo, pude viajar para Recife de avião”. Não existe romantismo em sua opção, em suas falas sobre o trabalho docente. E mesmo o idealismo, a vontade de fazer alguma coisa para melhorar a vida dos alunos, só apareceu naquele plano, ou sonho, de voltar para o Nordeste e trabalhar como alfabetizadora.

Mais uma vez, o paralelo com as professoras mineiras entrevistadas por Gomes (1994) parece enriquecedor. Naquele estudo, somente as professoras negras mencionaram necessidades materiais em sua escolha pelo magistério, enquanto a única branca ouvida falou em dom natural e num desejo de ser professora que vinha da infância, das brincadeiras de menina. Independentemente de qualquer veracidade quanto a optar pela carreira devido apenas a ideais ou devido a injunções materiais, parece que a representação dessa opção como vocação e da relação com o trabalho docente como parte de uma realização pessoal é mais forte entre as mulheres brancas do que entre as negras. É como se uma das características da imagem da professora primária ideal - carinhosa, dedicada, capaz de empatia com as crianças etc. - fosse a cor de sua pele, sendo mais fácil para as meninas e mulheres brancas identificarem-se com esse modelo ideal e internalizarem suas prescrições. Talvez por isso, as professoras negras possam falar mais claramente dos aspectos materiais de suas escolhas e estabelecer uma relação menos ambígua com a docência em sua dimensão de trabalho assalariado.

9. Questionário respondido por 512 dos 719 alunos da escola, em 1996, indicou que mais da metade deles eram filhos de trabalhadores e trabalhadoras manuais não especializados, dos quais $80 \%$ eram empregados domésticos ou de condomínios, tais como porteiros, zeladores, motoristas e empregadas domésticas. Contudo, $27 \%$ dos alunos provinham de famílias que podiam ser enquadradas nos setores médios, com pais ou mães ocupados em trabalhos não manuais que exigiam pelo menos escolaridade equivalente ao ensino médio. 
Quanto a Alda, o tema do trabalho parece mais importante para descrever sua trajetória do que os temas do cuidado, do idealismo ou da maternidade, essa mesma encarada como um trabalho, seja nas tarefas quotidianas de criar o filho, seja no fato de Alda ser também responsável por seu sustento. Ela trabalhou duro desde a infância, às vezes em mais de um emprego - escriturária e professora, costureira a domicílio e professora -, às vezes em dois turnos, em escolas diferentes e distantes entre si; além de fazer sozinha todo o serviço doméstico. Até 1996, quando seu filho ingressou no ensino fundamental e freqüentava a escola no mesmo horário que ela, fez arranjos complicados para cuidar dele, pagando vizinhas ou deixando-o numa escola de período integral.

Quando perguntada diretamente sobre a influência do fato de ter-se tornado mãe sobre sua relação com os alunos, ela foi clara:

A professora sem filhos é um pouco mais distante da criança, de entender a criança, de entender até a própria mãe da criança. E a professora com filho, ela ficou mais perto da criança e a entender até as suas reações [...] emotivamente. [...] E entender até às vezes a mãe, uma mãe que trabalha fora, que tem que educar, uma mãe que tem que se virar. [...] Que eu também tenho os mesmos problemas que ela e ela os mesmos que eu.

Alda dizia ter-se tornado mais maleável, mais humana, a partir dessa capacidade maior de empatia com o aluno e sua mãe, embora diferenciasse com ênfase seus sentimentos pelos alunos de seus sentimentos com o filho: "não é uma relação de mãe, de eu ser mãe, de eu ter de protegê-lo como se fosse meu filho".

Outras professoras tinham parentes próximos (filhos, irmãos) estudando na escola, o que tornava a presença do filho de Alda, Roberto, um fato normal. Mas a já delicada situação da professora se complicou quando surgiram conflitos, em meados de 1996, entre ela e a professora de Roberto, que acabou sendo transferido, a seu pedido, para outra classe. Esses conflitos se originaram, de acordo com Alda, no fato de a professora impedir o garoto de sair para o recreio e o lanche enquanto não terminasse a lição. Como Roberto, em geral, levava mais tempo que as outras crianças para terminar, começou a ficar vários dias sem lanche e Alda procurou a professora, explicando que ele tinha a saúde frágil e já tivera anemia “por não se alimentar direito". Depois dessa reclamação, a professora teria passado a procurar Alda em sua sala de aula ou mandar o menino, seja porque não havia comido o lanche, seja para Alda preencher ficha com informações, seja para mostrar uma lição feita incorretamente. Alda sentiu, pelo que conta, tanto a interferência em sua sala de aula, quanto o tipo de tratamento dado a seu filho: "Eu achei um absurdo, porque jamais eu iria fazer isso com o filho dela ou de seja quem for”. Alda acabou dirigindo-se à classe de Roberto e brigando com a professora, aos gritos, na porta da sala:

Porque eu também não tenho sangue de barata, naquele momento era o meu filho que estava numa situação de vexame. [...] Falei prá ela: Olha, isso não é motivo para que você me tire da minha sala de aula, eu estou trabalhando. [...] Então ela colocou que ele era o único que fazia aquilo, o único que era devagar, era o único incompetente, era o único que jamais teria competência de fazer alguma coisa na vida (ênfases da fala).

Levado o conflito à direção da escola, Alda pediu a transferência do garoto para outra turma, pois considerava que a professora o estava perseguindo. Diante da negativa em fazer a mudança, lembrou que uma outra aluna, filha de uma professora, havia sido transferida de sua própria turma, sem nenhuma intervenção da direção e sem nenhuma consulta a Alda, titular da classe. Essa diferença 
de tratamento caracterizava, para Alda, "um tipo de preconceito até" e acabou, ao que parece, sendo o argumento decisivo na transferência de Roberto.

Três elementos da situação da professora evidenciaram-se nesse episódio. Em primeiro lugar, sua posição de pouco poder, seja diante da direção da escola - pois a filha de outra professora realmente fora transferida a pedido da mãe, que não desejava ter a filha como aluna de Alda -, seja diante das colegas, que tendiam a desprezar suas opiniões em reuniões e a considerar como interferências suas tentativas de colaboração.

Em segundo lugar, o episódio também pôs em evidência possíveis situações de discriminação contra o filho de Alda, que, devido ao cabelo liso, possuía menos traços fenotípicos que pudessem caracterizá-lo como negro. $\mathrm{Pa}-$ rece, porém, que a mudança de turma foi bem sucedida, pois em 1997, Roberto freqüentou a classe de Ciclo Básico continuidade, estava perfeitamente alfabetizado e cursava a terceira série em 1998.

Finalmente, este foi um episódio emblemático das complexas inter-relações que Alda estabelecia entre sua situação de mãe e seu papel de professora. Como mãe, nessa como em outras situações que tive oportunidade de presenciar, Alda revelou-se atenciosa, amorosa, protetora e atenta ao desenvolvimento do filho, nos moldes da maternidade total. Assim, parece que, apesar das diferenças sociais e de suas experiências de socialização, Alda incorporara novas idéias de infância e prescrições de maternagem..$^{10}$ Como professora, contudo, sua prática com os alunos estava distante dessas idealizações.

Várias hipóteses surgiram, de início, para mim, para explicar essa diferença: Alda teria uma concepção de trabalho docente mais cognitivista, centrada na transmissão de conteúdos? Suas falas sobre "a professora ideal" - envolvida e dedicada - e suas dificuldades práticas em lidar com o conhecimento não apontavam nessa direção. Ou seu pouco envolvimento emocional decorreria apenas de sua relação com o trabalho docente como emprego, ganha-pão e da dificuldade em mobilizar energia para mais esse vínculo? Essa possibilidade parecia explicar em parte a situação.

Por outro lado, estaria Alda expressando em sua prática com os alunos um outro padrão de cuidado, mais próximo ao que vivenciara em sua infância na família? Se tomássemos exclusivamente seu fazer em sala de aula e suas experiências familiares, poderíamos pensar que ela estivesse acionando um outro modelo de relação adulto - crianças, mais controlador e centrado nos adultos, um modelo que eventualmente inclui o castigo físico como forma de educar e no qual se estabelecem relações mais distanciadas, pois 0 carinho é considerado mimo, que estraga a criança. Esse parece ter sido o modelo vivenciado por ela, em sua infância, ao longo dos anos 50 e 60, em Recife, como indicam seus depoimentos, e é, certamente, comum ainda hoje, especialmente entre famílias de camadas populares e/ou de origem rural (Gomes, 1986; Fonseca, 1997).

É possível mesmo especular se não estaria havendo uma mudança nas práticas de cuidado dentro das escolas de Ensino Fundamental, com o ingresso crescente na ocupação de professoras oriundas de famílias de baixa ren$\mathrm{da},{ }^{11}$ nas quais possivelmente o modelo adotado de relação entre adultos e crianças não corresponde integralmente à maternidade total e à infância moderna, podendo incluir práticas como a circulação de crianças e concepções diferenciadas de infância, responsabilidade parental e amor materno. Caso houvesse uma

10. Os termos maternagem e maternação têm sido utilizados nos estudos feministas brasileiros como tradução para o inglês mothering, a fim de enfatizar 0 aspectos sociais da criação dos filhos, em oposição aos aspectos biológicos (motherhood).

11. Infelizmente, não há dados estatísticos disponíveis para constatar essa tendência, percebida intuitivamente por todos que têm contato com as redes públicas de ensino no país. 
simples transposição das vivências e práticas familiares de cuidado e maternagem das professoras para as atividades de cuidado na escola, ante os alunos, deveríamos estar assistindo a uma mudança nos padrões de relação entre professoras e alunos e nos ideais de professora primária comprometida, carinhosa, envolvida emocionalmente e preocupada com aspectos não cognitivos de seus alunos.

Contudo, não é isso que ouvimos quando Alda fala sobre seu ideal de professor, no qual insinuam-se elementos das prescrições de cuidado predominantes:

E o professor ideal, ele estaria bem disponível, estaria assim, de corpo e alma dentro da profissão. [Seria muito envolvido com as crianças?] Seria muito envolvido com as crianças, demais. E seria uma pessoa muito esclarecida em toda área. Para poder ter uma condição melhor para... nossa! Um professor envolvido seria muito ... eu gostaria que meu filho tivesse um professor assim!

Se não aprendeu essas prescrições em sua infância, em suas relações familiares, possivelmente Alda as foi absorvendo ao longo da vida, no processo migratório, na convivência na metrópole e, também, em sua formação como professora, seja nos cursos que freqüentou, seja na prática profissional, conversando com as colegas, ouvindo exemplos e trocando experiências.

lsto é, há indicações de que se trata de um modelo de infância, de cuidado e de professora que se perpetua por meio da cultura escolar, o que poria em dúvida aquelas especulações quanto ao ingresso de novas concepções de relação entre adultos e crianças na escola com a entrada na carreira de professoras de origens sociais mais baixas. A própria experiência escolar de Alda, quando criança, parece ter-lhe ensinado esse modelo de professora - e possivelmente de mulher adulta em geral - envolvida e disponível. Ela descreve a professora que mais a marcou, com quem se identificava até no nome, aquela com quem aprendeu a ler, como atenta e carinhosa:

Então, aquela era escola de verdade, tinha tanque de areia, balanço e escorregador. Mas eu não brincava, era muito, muito quietinha, retraída, ficava sentada debaixo da janela. Então ela vinha, sentava, dividia comigo o lanche que ela levava e eram uns lanches muito gostosos. [...] No aniversário dela, ela levou um bolo de chocolate para nós, para as crianças, nunca me esqueço.

Assim, parece que, a despeito das práticas familiares em sua infância, Alda incorporara por processos que incluíam também a escolarização, a formação docente e a prática profissional, um ideal de infância, cuidado e relação adulto-crianças, que servia tanto de referencial para a criação de seu filho quanto, em alguma medida, como ideal de professora primária. $^{12}$

É possível, também, que a busca, nas relações com o filho, de um modelo que Alda considerava mais esclarecido e adequado, estivesse de acordo com seu processo de ascensão social, como forma de se diferenciar de sua família de origem e exibir um comportamento condizente com o almejado status de classe média. "A minha relação com meu pai e minha mãe foi muito diferente da minha relação com meu filho. Na relação com o Roberto, existe mais respeito um pelo outro, aquela preocupação de 'desculpa', 'dá licença'."

Outra possibilidade para explicar a postura de Alda ante seus alunos seria a de que, apesar de expressar idealmente esses padrões de relacionamento, ela não os tivesse incorpo-

12. Pode-se até mesmo aventar a hipótese de que, tal como verificou Luís Pereira nos anos 50, com relação à Escola Normal (Pereira, 1969), a escolarização e a formação docente estejam contribuindo para alterar práticas de maternagem e cuidado com os filhos entre as mulheres de camadas sociais que tiveram acesso mais recente à escola e que vêm, crescentemente, ingressando na carreira de professora primária. 
rado na prática, mantendo, tanto com o filho, quanto na sala de aula, o comportamento possivelmente mais internalizado, porque mais antigo, o modelo aprendido com seus pais. Mas sua relação com o filho, naquilo que foi possível observar, desmentia essa hipótese: Alda desenvolvia uma relação próxima às prescrições de cuidado, fazendo grandes esforços para estar com ele o maior número de horas possível cada dia; preocupando-se e responsabilizando-se por todos os aspectos de sua saúde, higiene, personalidade e desenvolvimento; colocando suas necessidades e desejos como prioridades; investindo grande energia em sua educação; agindo com ele de forma respeitosa, empática e carinhosa; culpando-se por seus fracassos etc.

Mas com relação aos alunos, como vimos, Alda agia de forma diferente. 0 que estaria estabelecendo, então, na sala de aula, a distância entre intenção e gesto, entre o ideal proclamado e a prática observada? Além dos fatores já mencionados quanto às condições de vida da professora e de sua insatisfação com o trabalho - seu cansaço, desgaste e as dificuldades enfrentadas a partir de situações de discriminação -, um outro elemento merece ser considerado.

É possível que os aspectos menos técnicos do trabalho docente, relativos ao cuidado, fossem excessivamente ameaçadores, trazendo à tona as semelhanças do trabalho na escola não apenas com o papel materno, mas também com o papel da empregada doméstica, uma das principais responsáveis pelo cuidado das crianças de camadas médias no Brasil. Negra, oriunda de uma família operária pobre e pouco escolarizada de Recife, Alda parecia lutar constantemente, contra um possivel rebaixamento social, real ou simbólico. Especialmente as tarefas desprestigiadas do cuidado com crianças - relativas à higiene, vigilância, nutrição - poderiam estar próximas demais do trabalho da empregada doméstica e, assim, serem ameaçadoras.

Inicialmente, Alda mencionou o trabalho de babá como referência de desqualificação de suas atividades como professora, ao comentar os problemas de disciplina de uma classe, na qual pouco conseguia desenvolver qualquer conteúdo:

0 negócio é o seguinte: se você colocar um avental, é a mesma coisa que babá. Parece que os poros deles são pura agitação. É uma classe que tem dificuldade para aprender. Você precisa trabalhar com coisas concretas, assim [gesto], que eles possam ver. Abstração não adianta ficar batendo, Português, Matemática não adianta.

Esse tipo de comparação não era comum entre as demais professoras e professor da escola pesquisada.

Noutro momento, falando sobre as tarefas não pedagógicas que sobrecarregariam as professoras, ela retomou a comparação:

Às vezes eu falo [para os alunos]: "Olha, não sou babá”. Na hora que eles expõem para mim tantas coisas assim, ao mesmo tempo, eu falo: “Não, eu não estou aqui para ficar cuidando dos detalhes da vida de vocês. Isso é da competência de quem está cuidando de vocês durante 24 horas".

A ênfase de Alda nos aspectos ligados ao saber pedagógico e ao conhecimento em geral, ao falar do trabalho de professora, parece articular-se a essa necessidade de diferenciação. Por outro lado, sua precariedade de formação intelectual tornava difícil a realização plena de um projeto de trabalho docente centrado no saber, na transmissão de conhecimentos e na técnica pedagógica.

Enfim, a necessidade de afastar-se de um padrão que identificava com as empregadas domésticas tornou-se evidente quando fez um balanço de sua própria trajetória:

Eu poderia estar numa... eu seria uma doméstica, porque eu estou vindo de uma família muito simples. É formado lá o quê? Domésticas. 
Então eu poderia ser também uma doméstica igual minhas tias, mas eu lutei muito contra isso.

[...] Não me via assim como doméstica na casa, cozinhando, lavando, esfregando. Nossa! Eu tinha que fazer alguma coisa, ter uma profissão.

[...] Elas [as tias] foram para ser domésticas muito cedo, meninas, em casas de família. Elas foram ser domésticas, até hoje não foram à escola. Então, elas não sabem ler até hoje.

Por meio da escolarização, valorizada pela família - pois, apesar de analfabeto, o pai de Alda exigia o bom desempenho escolar dos filhos, punindo-os com surras diante de reclamações da escola ou notas baixas -, ela conseguiu "uma profissão". Mas o fantasma do "trabalho em casa de família" certamente assombrava sua relação com os alunos, filhos dos outros a solicitar sua atenção, seu envolvimento, seu tempo e seu trabalho. ${ }^{13}$

Finalmente, já na terceira entrevista, ao falar sobre aquela sua professora primária mais querida, Alda revelou, de forma comovente, como sua escolha profissional e toda sua trajetória estavam marcadas pela diferença social e racial:

Coincidiu que a minha tia trabalhava para a família da minha professora. No começo, a gente não sabia, mas depois, conversando com minha tia, acabamos descobrindo. Então eu ia com a professora depois da escola para a casa dela e ficava esperando até a hora da minha tia sair para irmos para casa, que a minha tia morava no mesmo bairro que eu. [...] Eu ficava sentada na sala, morria de vergonha, ficava lá sentadinha, vendo televisão. Me lembro que era um sobrado grande, com muro alto, um jardim bonito. Tinha quintal, mas eu nunca fui no quintal. Ficava lá quietinha na sala até a hora da minha tia ir embora. Eu tinha vergonha, porque às vezes vinha o noivo da minha professora, o noivo da irmã dela. Minha tia cozinhava prá família dela. Era uma casa muito grande, uma sala em "L", eu me lembro da televisão lá no fundo.
Hilary Graham (1991), pesquisadora britânica, há muitos anos envolvida em pesquisas sobre o cuidado, oferece pistas interessantes para analisarmos a situação de Alda, num artigo em que revisa as concepções predominantes na literatura de seu país, em busca de uma reconceituação capaz de abranger a análise do serviço doméstico assalariado. Nessa busca, ela recorre à produção do feminismo anti-racista norte-americano, que critica a definição estreita de trabalho doméstico (ou reprodutivo) como trabalho feito pelas mulheres para suas próprias famílias no interior de seus lares. Assim definido, o conceito de trabalho doméstico obscurece o trabalho feito pelas empregadas domésticas em sua maioria não-brancas, nos E.U.A. e Inglaterra, como no Brasil - nos lares dos brancos. Se, para as mulheres brancas dos setores médios, o trabalho doméstico é um divisor de águas entre a vida pública e a vida privada, a família é sinônimo de esfera privada e os trabalhos relacionados ao cuidado a seus familiares são vividos como confinamento e opressão, o mesmo não pode ser afirmado para todas as mulheres. Para as não-brancas, desde a escravidão até o serviço doméstico assalariado, o trabalho fora de suas próprias famílias - freqüentemente um trabalho de cuidar da família dos outros - teve precedência sobre as necessidades de seus filhos e parentes. E a ausência de uma esfera privada claramente definida, mais do que sua presença, estruturou suas experiências de opressão. Para as mulheres envolvidas nesse tipo de relação, a possibilidade de cuidar de sua própria família e mantê-la unida teria o sentido de conquista, liberdade e até de resistência à opressão racial e de classe; enquanto o cuidado com a família dos outros seria vivido como situação emblemática de sua opressão.

13. Segundo dados da PNAD de $1997,31,2 \%$ das mulheres brasileiras negras, pardas e amarelas ocupadas em atividades não agrícolas são empregadas domésticas (Lavinas et alli, 1998), estatísticas que revelam o grau de realismo dos temores de Alda. 
São análises que dão profundidade e perspectiva ao quadro da menininha negra assentada na sala da "casa grande", esperando a tia cozinheira terminar de fazer "coisas gostosas" para a família da jovem professora branca. À luz dessas interpretações, podemos ver também com outros olhos Alda aos gritos com a professora de seu filho: "Naquele momento, era o meu filho que estava em situação de vexame [...] eu estou trabalhando". Podemos ver Alda em tantas situações lutando para cuidar do próprio filho de acordo com os padrões prescritos, defendendo com todas as forças sua relação com ele e recusando as dimensões de cuidado do trabalho docente. Seu esforço por "ter uma profissão", enfatizar as dimensões técnicas do trabalho docente e as diferenças na relação com os alunos e com o filho tinha, antes de mais nada, o sentido de afastar-se do padrão de empregada doméstica - tão ameaçadoramente próximo - e garantir a diferenciação de uma esfera de vida privada bem demarcada. Além disso, ela tinha muito mais necessidade de refrear seu envolvimento afetivo na escola e sublinhar as diferenças entre trabalho profissional e trabalho doméstico, para afirmar-se na profissão, do que as demais professoras daquela escola - que, em geral, agiam até mesmo na direção contrária. 0 trabalho como professora era seu emprego, não sua paixão, sua vocação ou o centro de sua realização pessoal. E a delimitação de uma esfera privada em sua vida era um privilégio ${ }^{14}$ precariamente estabelecido, pelo qual ela ainda precisava lutar.

Diante disso, em sua visão da escola e do trabalho docente, as crianças e suas relações com elas ficavam esfumadas, em segundo plano, assim como o caráter relacional da atividade pedagógica. Nas memórias e mesmo na relação cotidiana, elas apareciam como grupos, tipos, crianças em geral, sem nomes nem individualidade, pois desinvestidas de um vínculo afetivo e um aporte emocional.

A história de Alda, assim, indica antes de mais nada, a necessidade de nomear e discutir abertamente as relações inter-étnicas e o racismo no interior das escolas, a começar dentro do próprio grupo de professores e professoras. Ao lado disso, se estamos convencidos da relevância para o ensino das práticas de cuidado e das dimensões relacionais, é preciso também nomeá-las e trazê-las para primeiro plano nas discussões pedagógicas, de forma que elas adquiram legitimidade como parte de uma prática profissional. Quando o cuidado infantil passar a ser objeto de reflexão sistemática e coletiva, poderemos criticar as conotações de filantropia, domesticidade e não profissionalismo a ele associadas hoje e oferecer instrumentos e apoio para que sua prática não dependa exclusivamente da personalidade e história de vida de cada docente. E, talvez, então, professoras como Alda possam assumir as dimensões de cuidado do trabalho docente com crianças, sem verem ameaçadas suas vidas privadas e sua profissionalização e sem perderem o compromisso que hoje manifestam com o ensino como trabalho assalariado.

14. 0 historiador Luís Filipe de Alencastro (1997) lembra que as palavras latinas privatus (privado) e privus-lex ou privilegium (lei para um particular, privilégio) são variantes originadas de uma mesma raiz, privus.

\section{Referências biliográficas}

ALENCASTRO, Luís Felipe de. Vida privada e ordem privada no Império. In: NOVAIS, Fernando (coord.); ALENCASTRO, Luís Felipe de (org.). História da vida privada no Brasil II: Império. São Paulo: Companhia das Letras, 1997.

CARVALHO, Marília Pinto de. Professor, professora: um olhar sobre as práticas docentes nas séries iniciais do ensino fundamental. São Paulo, 1998. Tese (Doutorado) - Faculdade de Educação da USP. 
DAVID, Miriam E. Theories of family change, motherhood and education. In: ARNOT, Madeleine; WEILER, Kathleen (eds.) Feminism and social justice in education: international perspectives. New York: The Falmer Press, 1993.

FONSECA, Claudia. Ser mulher, mãe e pobre. In: PRIORE, Mary del. (org.). História das mulheres no Brasil. São Paulo: Contexto, 1997.

GOMES, Jerusa Vieira. Socialização: um estudo com famílias de migrantes em bairro periférico de São Paulo. São Paulo, 1986. Tese (Doutorado) - Instituto de Psicologia da USP.

GOMES, Nilma Lino. A trajetória escolar de professoras negras e sua incidência na construção da identidade racial: um estudo de caso em uma escola municipal de Belo Horizonte. Belo Horizonte, 1994. Dissertação (Mestrado) Universidade Federal de Minas Gerais.

GRAHAM, Hilary. The concept of caring in feminist research: the case of domestic service. Sociology, v. 25, n.1, p.61-78, feb. 1991.

HADDAD, Lenira. A creche em busca de identidade: perspectivas e conflitos na construção de um projeto educativo. São Paulo: Loyola, 1991.

LAVINAS, Lena et alli. Diferenciais por gênero e raça no mercado de trabalho. Rio de Janeiro, 1998. [mimeografado]

LIGHTFOOT, Sara L. Family-school interactions: the cultural image of mothers and teachers. Sings: journal of women in culture and society, Chicago, v.3, n.2, p.395-408, 1977.

LUDKE, Menga. Sobre a socialização profissional dos professores. Cadernos de Pesquisa, São Paulo, n.99, p.5-15, nov. 1996.

MANICOM, Ann. Feminist framework and teacher education. Journal of Education, Boston, v.1, n.166, p.77-88, mar. 1984.

NOVELINO, Aída Maria. A cartilha da mãe perfeita: um discurso normatizador na psicologia de mídia. São Paulo; 1989. Dissertação (Mestrado) - Pontifícia Universidade Católica de São Paulo, Programa de Psicologia Social.

PEREIRA, Luís. O magistério primário numa sociedade de classes. São Paulo: Pioneira, 1969.

PERRENOUD, Philippe. Práticas pedagógicas, profissão docente e formação: perspectivas sociológicas. Lisboa: Dom Quixote / Instituto de Inovação Educacional, 1993.

PIERUCCI, Antônio Flávio. As bases da nova direita. Novos Estudos CEBRAP, São Paulo, n.19, p.26-45, dez. 1987.

ROSEMBERG, Fulvia. Raça e desigualdade educacional no Brasil. In: AQUINO, Julio G. (org.). Diferenças e preconceito na escola: alternativas teóricas e práticas. São Paulo: Summus, 1998.

SILVA, N.V.; HASENBALG, C.A. (orgs.). Relações raciais no Brasil contemporâneo. Rio de Janeiro: Rio Fundo, 1992.

TARDIF, Maurice et alli. Os professores face ao saber: esboço de uma problemática do saber docente. Teoria e Educação, Porto Alegre, n.4, p.215-33, 1991.

Recebido em 24 ago. 1999

Aprovado em 16 set. 1999 